\title{
Productivity of short crop rotations and humus state of sod- podzolic soil at different fertilizer systems
}

Parkhomenko M.

NSC «Institute of agriculture of NAAS», Mashyno-budivnykiv Str., 2b, Chabany, Kyiv-Sviatoshyn region, Kyiv oblast, 08162, Ukraine, e-mail: miroslav_parkhomenko@ukr.net,

Productivity of short crop rotations and humus state of sod-podzolic soil at different fertilizer systems

The purpose. To study influence of traditional organic-mineral, mineral, alternative (ecological) fertilizer systems on productivity of crops and productivity of crop rotations, receipt in soil of organic substance with roots, postharvest residues and collateral products of crops of crop rotations. Methods. Field, laboratory, calculation-comparative, mathematical-statistical. They spent experiments according to conventional procedures in farming agriculture and plant growing. Results. Influence of traditional, mineral, organic and alternative fertilizer systems on productivity of grain and grain-potato short crop rotations is established. Receipts in soil of organic substance with roots, postharvest residues, collateral products and green manure crop mass are established. Influence of fertilizer systems in crop rotations on humus state of sod-podzolic sandy loam soil is specified. Conclusions. In conditions of Left-bank Chernihiv Polissia it is established that grain short crop rotation has ensured on the average on 0,89 $\mathrm{t}$ of feeding units/hectare above productivity, than grain-potato. At higher productivity with secondary products and the rooted residues in grain short crop rotation in soil has arrived on the average on 2,5 t/hectares more of organic mass. Thus grain short crop rotation has ensured sufficient balance of humus in conditions of Polissia on sod-podzolic sandy loam soil. The highest productivity in both crop rotations is gained at the alternative fertilizer system $\left(\mathrm{N}_{68} \mathrm{P}_{53} \mathrm{~K}_{60}+\right.$ green manure crop+PP): $6,51 \mathrm{t}$ of feeding units/hectare in grain short crop rotation and 5,53 t of feeding units/hectare in grainpotato, that accordingly on 94,5 and $98,9 \%$ is more, than in control.

Key words: short crop rotations, fertilizer systems, sod-podzolic sandy loam soils, humus state, productivity.

DOI: https://doi.org/10.31073/agrovisnyk201905-10

Economic stability and economic security of agricultural production require further improvement of generally accepted agro-systems of land use [1]. Today, the technologies, adapted to modern land use , are insufficiently developed. The main features of sustainable land use are the narrowing of specialization, the introduction of short-term crop rotation, the decrease of mineral fertilizers inputs, and the use of green manure and by-products as organic fertilizers [2, 3].

To ensure efficient and competitive agrarian production, it is necessary to ensure sufficiently high soil quality indicators, which depend predominantly on the content of organic matter. Therefore, all elements of agrotechnologies should be aimed at achieving a deficit-free balance of organic matter in the soil $[4,5]$, which is a key element in the system to overcome the problem of balancing environmental and economic factors [6, $7,8,9]$. The rational use of fertilizer systems plays a defining role in the reproduction and increase of soil fertility, and especially in sod-podzol soils [2, 10].

The purpose of the research was to study the influence of traditional (organic and mineral), mineral, alternative (ecological) fertilizer systems on crop yield, crop rotation productivity and organic matter inputs with roots, plant residues and crops by-products of crop rotation.

Research methodology. The research was conducted in the long-term stationary experiment of the Scientific Support Department of Agro-Industrial Production of the Institute of Agricultural Microbiology and 
Agro-Industrial Production of NAAS. The stationary research was found in 1980, as two links of 8-field crop rotation. In 2006, the reconstruction of the experiment was carried out, therefore, since this period, the experiment is considered as two short-term four-field crop rotations: crop rotation I - grain crop rotation (Clover - Winter wheat - Corn - Spring wheat) and crop rotation II - grain-potato crop rotation (Narrow-leaf lupine - Winter rye - Potatoes - Hulless oat).

In 2006-2018, the traditional (organic and mineral) fertilizer system envisaged the input of $10 \mathrm{t} / \mathrm{ha}$ of animal manure $+\mathrm{N}_{68} \mathrm{P}_{53} \mathrm{~K}_{60} \mathrm{~kg} / \mathrm{ha}$; the mineral fertilizer system $-\mathrm{N}_{68} \mathrm{P}_{53} \mathrm{~K}_{60} \mathrm{~kg} / \mathrm{ha}$; for organic fertilizer system $20 \mathrm{t} / \mathrm{ha}$ of animal manure; variant of ecological (alternative) fertilizer system, introduced in 2006 included narrow-leaf lupine as green manure + by-products $+\mathrm{N}_{68} \mathrm{P}_{53} \mathrm{~K}_{60} \mathrm{~kg} /$ hectare of crop rotation.

One of the tasks of our research was to determine how the crop rotation factor in various fertilizer systems affects the humus state of sod-podzol sandy soils. In order to solve this problem in 2017,2018 , soil samples were selected and analyzed in grain and grain-potato crop rotations.

The soil's humus level is determined by the amount of organic matter input to the soil [11]. The analysis showed that in grain short-term crop rotation, the highest input of organic matter with roots and afterharvesting plant residues was obtained from traditional $(7.21 \mathrm{t} / \mathrm{ha})$ and organic $(7.13 \mathrm{t} / \mathrm{ha})$ fertilizer systems. The addition compared with control variant was $2,12 \mathrm{t} /$ ha and 2,04 $\mathrm{t} /$ ha respectively. Under the mineral fertilizer system, the input of organic matter had a slight difference comparing to the control variant only $0.78 \mathrm{t} /$ ha or $15 \%$ (Table 1 ).

Under the alternative fertilizer system with joint use of by-products and green manure on the background of NPK, the organic matter input was lower than under traditional and organic fertilizer systems by $0.52 \mathrm{t} /$ ha and $0.44 \mathrm{t} /$ ha or by $7.7 \%$ and $6.6 \%$ respectively (Table 1 ).

Determination of humus stocks has shown that the alternative fertilizer system due to the receipt of less organic mass in the soil comparing with traditional, had a lower positive effect on the humus state than traditional (organic and mineral) and organic fertilizer systems by $2 \mathrm{t} /$ ha and $7.4 \mathrm{t} /$ ha respectively. The high level of mineralization processes was fixed during joint use of mineral fertilizers and green manuring. $A$ similar regularity of the fertilizer systems influence on the humus state is observed in both crop rotations.

Table 1. Productivity of short-term crop rotations and organic matter inputs under different fertilizer systems on sod-podzol sandy soils, t / ha, 2007-2018.

\begin{tabular}{|c|c|c|c|c|c|c|c|}
\hline \multirow{3}{*}{ № } & \multirow{3}{*}{ Fertilizer systems } & \multicolumn{3}{|c|}{$\begin{array}{l}\text { Grain crop rotation (Clover - } \\
\text { Winter wheat - Corn - Spring } \\
\text { wheat) }\end{array}$} & \multicolumn{3}{|c|}{$\begin{array}{l}\text { Grain-potato crop rotation } \\
\text { (Lupine - Winter rye - } \\
\text { Potatoes - Oats) }\end{array}$} \\
\hline & & \multicolumn{2}{|c|}{ Productivity } & \multirow{2}{*}{\begin{tabular}{|l|}
$\begin{array}{l}\text { Organic } \\
\text { matter } \\
\text { inputs }\end{array}$ \\
Roots + \\
plant \\
residues
\end{tabular}} & \multicolumn{2}{|c|}{ Productivity } & \multirow{2}{*}{\begin{tabular}{|l|}
$\begin{array}{l}\text { Organic } \\
\text { matter } \\
\text { inputs }\end{array}$ \\
Roots + \\
plant \\
residues
\end{tabular}} \\
\hline & & $\begin{array}{l}\text { feed } \\
\text { units }\end{array}$ & $\begin{array}{l}\text { grain } \\
\text { units }\end{array}$ & & $\begin{array}{l}\text { feed } \\
\text { units }\end{array}$ & $\begin{array}{l}\text { grain } \\
\text { units }\end{array}$ & \\
\hline 1 & Control (No fertilizer) & 3,35 & 2,87 & 5,09 & 2,78 & 2,10 & 3,20 \\
\hline 2 & Mineral fertilizer system $\left(\mathrm{N}_{68} \mathrm{P}_{53} \mathrm{~K}_{60}\right)$ & 4,93 & 2,89 & 5,87 & 4,22 & 3,10 & 3,62 \\
\hline 3 & $\begin{array}{l}\text { Traditional (organic and mineral) } \\
\text { fertilizer system (animal manure (10 } \\
\left.\text { t/ha) }+\mathrm{N}_{68} \mathrm{P}_{53} \mathrm{~K}_{60}\right)\end{array}$ & 6,06 & 3,61 & 7,21 & 5,15 & 3,79 & 4,30 \\
\hline 4 & $\begin{array}{l}\text { Alternative fertilizer system } \\
\text { (N68 } P_{53} K_{60}+\text { green manure + by- } \\
\text { products) }\end{array}$ & 6,51 & 3,79 & 6,69 & 5,53 & 4,02 & 4,40 \\
\hline 5 & $\begin{array}{l}\text { Organic fertilizer system (animal } \\
\text { manure }-10 \mathrm{t} / \mathrm{ha} \text { ) }\end{array}$ & 6,30 & 3,63 & 7,13 & 5,03 & 3,60 & 4,00 \\
\hline \multicolumn{2}{|r|}{ Averages } & 5,43 & 3,36 & 6,40 & 4,54 & 3,32 & 3,90 \\
\hline \multicolumn{2}{|c|}{$\mathrm{LSD}_{0,95}$} & 0,27 & 0,17 & 0,32 & 0,23 & 0,17 & 0,20 \\
\hline
\end{tabular}


In the crop rotation I and in crop rotation II, the highest humus level in the soil was composed under organic fertilizer system (the input of animal manure is $20 \mathrm{t} / \mathrm{ha}$ ). Humus stocks in the layer $0-20 \mathrm{~cm}$ in grain rotation I are 12,7 t/ha higher than in the control variant (Table 2).

Table 2.Humus state of sod-podzolic soils for long-term use in crop rotation technologies of different levels of biologization

\begin{tabular}{|c|c|c|c|c|c|c|c|c|c|}
\hline \multirow{3}{*}{$\begin{array}{l}\text { № } \\
\text { var. }\end{array}$} & \multirow{3}{*}{ Fertilizer systems } & \multicolumn{4}{|c|}{$\begin{array}{l}\text { Grain crop rotation (Clover - } \\
\text { Winter wheat - Corn - Spring } \\
\text { wheat) }\end{array}$} & \multicolumn{4}{|c|}{$\begin{array}{l}\text { Grain-potato crop rotation } \\
\text { (Lupine - Winter rye - } \\
\text { Potatoes - Oats) }\end{array}$} \\
\hline & & \multicolumn{2}{|c|}{ Humus content } & \multicolumn{2}{|c|}{ +/- to control } & \multicolumn{2}{|c|}{$\begin{array}{l}\text { Humus } \\
\text { content }\end{array}$} & \multicolumn{2}{|c|}{ +/- to control } \\
\hline & & $\%$ & т/га & т/га & $\%$ & $\%$ & т/га & т/га & $\%$ \\
\hline 1 & Control (No fertilizer) & 0,97 & 28,7 & - & - & 0,84 & 24,7 & - & - \\
\hline 2 & $\begin{array}{l}\text { Mineral fertilizer system } \\
\left(\mathrm{N}_{68} \mathrm{P}_{53} \mathrm{~K}_{60}\right)\end{array}$ & 1,02 & 30,0 & 1,3 & 4,6 & 0,88 & 26,0 & 1,3 & 5,4 \\
\hline 3 & $\begin{array}{l}\text { Traditional (organic and mineral) } \\
\text { fertilizer system (animal manure } \\
\left.(10 \mathrm{t} / \mathrm{ha})+\mathrm{N}_{68} \mathrm{P}_{53} \mathrm{~K}_{60}\right)\end{array}$ & 1,22 & 36,0 & 7,3 & 25,3 & 1,02 & 30,2 & 5,5 & 22,2 \\
\hline 4 & $\begin{array}{l}\text { Alternative fertilizer system } \\
\left(\mathrm{N}_{68} \mathrm{P}_{53} \mathrm{~K}_{60}+\text { green manure + by- }\right. \\
\text { products) }\end{array}$ & 1,15 & 34,0 & 5,3 & 18,6 & 0,94 & 27,8 & 3,1 & 12,6 \\
\hline 5 & $\begin{array}{l}\text { Organic fertilizer system (animal } \\
\text { manure }-10 \mathrm{t} / \mathrm{ha} \text { ) }\end{array}$ & 1,40 & 41,4 & 12,7 & 44,3 & 1,11 & 32,9 & 8,1 & 32,9 \\
\hline \multicolumn{2}{|c|}{ Averages } & 1,15 & 34,0 & 6,7 & 23,2 & 0,96 & 28,4 & 4,5 & 18,3 \\
\hline
\end{tabular}

In the grain-potato crop rotation, the addition compared with control variant was $8.1 \mathrm{t} /$ ha. The high positive effect was on traditional technology. In this variant, at half-dose of animal manure, but under the influence of mineral fertilizers, in crop rotation I the stock of humus increased by $7.3 \mathrm{t} / \mathrm{ha}$, in crop rotation II by $5.5 \mathrm{t} / \mathrm{ha}$. The mineral fertilizer system has no high positive effect on the humus level. At the same time, in both crop rotations, a slight increase in the range of $4.6-5.4 \%$ is determined.

The dependence of the humus state on the type of crop rotation characterizes the average data of its stocks on control variants and average figures for different growing technologies. It was determined that they were higher in grain crop rotation compared to grain-potato crop rotation by $4 \mathrm{t} / \mathrm{ha}$ or by $15 \%$. On average, this advantage was $4.5 \mathrm{t} /$ ha or almost $17 \%$.

The effectiveness of crop rotation can be estimated by their productivity on non-fertilized control and by the average estimation of cultivation technologies. In control variants without fertilizers for many years, productivity of crop rotation in feed units was: in grain-potatoes - 2,78 tons of feed units per hectare, in grain crop rotation $-3,35$ tons of feed units per hectare. Regardless the type of crop rotation, high productivity was provided by the traditional fertilizer system (Table 1). Under favorable nitrogen regime of the soil, the alternative technology influenced positively the productivity of crop rotation with the use of intermediate green manuring and by-products instead of animal manure. 


\section{Conclusions}

It is fixed that grain short-term crop rotation yielded higher productivity than grain-potatoes' on average by 0.89 tons of feed units per ha in soil-climatic conditions of the Left Bank Chernihiv Polissya. Cereal short-term crop rotation gives more organic matter into the soil - an average of $2.5 \mathrm{t} /$ ha. Thus, grain short-term crop rotation ensured a deficit-free balance of humus in Polissya region on sod-podzolic sandy soils. The highest productivity in both crop rotations was fixed for an alternative fertilizer system $\left(\mathrm{N}_{68} \mathrm{P}_{53} \mathrm{~K}_{60}+\right.$ green manure + post-harvest residues): 6.51 tons of feed units per ha in cereal short-term crop rotation and $5.53 \mathrm{t}$ tons of feed units per ha in cereal-potatoes', that is $94.5 \%$ and $98.9 \%$ more comparing with control variant.

\section{References}

1. Roberts T.L. (2007) The foundation of best management practices for fertilizer. International fertilizer association international workshop on fertilizer best management practices 7-9 March 2007, Brussels, Belgium. P. 29-32.

2. Baliuk S. A., Miroshnychenko M. M. (Eds.) (2016) Systemy udobrennya silskohospodarskykh kultur u zemlerobstvi pochatku XXI stolittya. [Fertilization systems of agricultural crops in agriculture at the beginning of the XXI century]. Kyiv, Alpha-stevia. 400 p. [in Ukrainian].

3. Beegle D.B., Carton O.T., Bailey J.S. (2000) Nutrient management planning: justification, theory, practice. The Journal of Environmental Quality. № 29. P. 72-79.

4. Williams V.R. (2019) Pochvovedeniye. Izbrannyye sochineniya. [Soil science. Selected works]. Moskva: Izdatelstvo Yurayt. 344 p. [in Russian].

5. Mazur G. A. (2000). Rol humusu v rodyuchosti gruntiv ta vidtvorennya yoho vmistu. [The role of humus in soil fertility and reproduction of its content]. Visnyk ahrarnoi nauky. Special issue. P. 12-15. [in Ukrainian].

6. Kalinchik M.V. (1997) Naukovi osnovy ekonomichnoyi adaptatsiyi silskoho hospodarstva do navkolyshnoho seredovyshcha. [Scientific fundamentals of economic adaptation of agriculture to the environment]. Kyiv, RVPS Ukrainy NAN Ukrainy. 263 p. [in Ukrainian].

7. Tsvei Ya.P. (2014). Rodiuchist gruntiv i produktyvnist sivozmin. [Soil fertility and crop rotation productivity]. Kyiv: Komprynt. 413 p. [in Ukrainian].

8. Medvediev V.V., Chesniak H.la., Laktionova T.M. et al. (Medvediev V.V. Ed.). (1992). Rodyuchist gruntiv: monitorynh ta upravlinnya. [Soil fertility: monitoring and management]. Kyiv: Urozhay. 248 p. [in Ukrainian].

9. Tarariko Ju.O. (2005) Formuvannya stalykh ahroekosystem: teoriya i praktyka. [Sustainable Agroecosystems Formation: Theory and Practice] Kyiv: Agrar. science. 508 p. [in Ukrainian].

10. Tarariko Ju.O., Ivaschenko O. O., Berdnikov O.M. et al. (2004) Suchasni tekhnolohiyi vidtvorennya rodyuchosti gruntiv ta pidvyshchennya produktyvnosti ahroekosystem. Naukovo-tekhnolohichne zabezpechennya ahrarnoho vyrobnytstva. [Modern technologies of soil fertility reproduction and agroecosystem productivity increase. Scientific and technological support of agrarian production]. Kyiv: Agrar. science. 126 p. [in Ukrainian].

11. Levin F.I. (1977). Kolichestvo rastitelnykh ostatkov $\vee$ posevakh polevykh kultur i yego opredeleniye po urozhayu osnovnoy produktsii. [The amount of plant residues in crops of field crops and its determination by the yield of the main products]. Agrokhimiya. № 8. P. 36-41. [in Russian]. 